\title{
Breeding, Growth and Resistance to Infection of Mice Fed on Six Natural Diets*
}

\author{
By J. W. HOWIE AND G. PORTER \\ Rowett Research Institute, Bucksburn, Aberdeenshire
}

(Received 3 April 1950)

In their comprehensive review, 'Influence of nutrition in experimental infection', Clark, McClung, Pinkerton, Price, Schneider \& Trager (1949) noted that 'the great diversity of the experiments and the not infrequent inadequacy of controls, present such confusing and at times conflicting results that any attempt to generalize would seem premature'. They concluded that: 'Further efforts to unravel the snarled skein should continue.' 'This is a good summary of the present position.

In a series of valuable experiments Schneider (1948) defined a suitable technique for studying the influence of diet on salmonella infection of mice. He found (Schneider, 1949) that whole wheat contained a substance that he termed 'the mouse-salmonellosis resistance factor'. By fractionation studies he found that this factor was concentrated in wheat germ and began work for its isolation and characterization.

Another approach was indicated by Howie (1948-9), who proposed to test the resistance to infection of young mice born of parents fed on natural diets and mated continuously in order that this stress might reveal possible dietary imperfections, as described by Bruce \& Emmens (1948). In accordance with this plan the work described here was undertaken to see whether the resistance to infection of animals fed on a particular diet was correlated with the value of the diet as judged by its capacity to support reproduction and growth. Sengupta \& Howie (1948-9) described differences in the resistance to experimental tuberculosis of mice bred and reared on two diets of natural food (diets I and 2). These differences, though not great, were statistically significant. It seemed useful to attempt to increase the differences in resistance by modifying the diets; this paper gives the results of attempts to do this.

\section{METHODS}

Mice. The mice employed were albinos of the W-Swiss strain bred in the Institute colony, whose origin was described by Sengupta \& Howie (1948-9).

Mating procedures. The system of monogamously mated pairs described by Bruce \& Emmens (1948) was used in these experiments. All the parent mice for the experiment were born between 21 and 29 July 1948. They were born of animals fed on diet 3 (see below) and were themselves fed on diet I (see below) until given the appropriate experimental diet, numbered $1,2,3,4,5$ or 24 (see below). The feeding of the experimental diets was begun when the pairs were mated on 4 October 1948, i.e. when they

- As used in this paper the term 'natural diet' means a diet of foodstuffs commonly used in animal husbandry, i.e. not a 'synthetic' or chemically defined diet. 
were between 65 and 73 days of age. For each of the six diets tested, twenty-six female mice were continuously mated with twenty-six male mice. Each mated pair had a separate cage 12 in. $\times 6$ in. $\times 6$ in. Throughout this experiment all cages rested on sawdust and each two animals had access to their own faeces. The males remained continuously with the females until the males were removed on 4 April 1949, i.e. 6 months after the first mating. The experiment ended on 24 May 1949, when the last litter was weaned. At mating the mice were divided into groups that were as even as possible in weight, the mean weights for the females being: diet I, $21 \cdot 9 \mathrm{~g}$; $\operatorname{diet} 2,2 \mathrm{I} \cdot 5 \mathrm{~g}$.; diet $3,2 \mathrm{I} \cdot \mathrm{I}$ g.; diet $4,20 \cdot 6 \mathrm{~g}$; diet $5,2 \mathrm{r} \cdot 0 \mathrm{~g}$.; and diet $24,2 \mathrm{I} \cdot 3 \mathrm{~g}$. Litter-mates were distributed among the six diets and brother-sister mating was avoided. Young mice were weaned at $2 \mathrm{I}$ days of age and for each mated pair a record card was kept showing the number of young born and weaned and the weight of the young at weaning.

The temperature of the animal house was kept as near $70^{\circ} \mathrm{F}$. as could be arranged in the temporary building available. Apart from one sudden fall, from 68 to $42^{\circ} \mathrm{F}$. on the night of 8-9 April 1949, excursions of temperature were few and slight.

Growth test. The ability of the test diets to support growth was examined by weekly weighing of a group of from twenty-one to thirty-seven young mice bred on each diet, litter-mate brothers and sisters being used to form the test groups wherever possible. Weekly weighings began when the mice were weaned at 3 weeks of age and were continued until they were I I weeks old. After being weaned each mouse was housed in a separate cage 6 in. $\times 4$ in. $\times 4$ in. and identified by two numbers, one for the litter and one for the individual.

Tests of resistance to infection. For tests of resistance to infection the animals were caged individually as for the growth test and were transferred to a separate room in a separate building with separate attendants. Two cultures were used to test resistance to bacterial infection. (I) Mycobacterium tuberculosis $\mathrm{H} 905$ was grown and $0.5-0.75 \mathrm{mg}$. of culture was injected intravenously, in $0.1 \mathrm{ml}$. sterile water, as described by Sengupta \& Howie (1948-9). (2) Salmonella enteritidis MT-I-A was grown and I-2 million organisms were given by stomach catheter as described by Schneider \& Webster (1945). This culture when used by Schneider (1946) after mouse passage and colony selection was found unsuitable for eliciting differences of resistance due to feeding of different diets, but after subculture it regained its suitability for this type of work (Schneider, personal communication, 1947). The resistance of the infected animals was assessed by the proportion of survivors 28 days after infection. In four of the five infection tests the animals were all within a week of the same age and in the other (no. 2 of Table 10 ) within 12 days.

Experimental diets. The six diets tested were numbered I, 2, 3, 4, 5 and 24. Diet I was the modified Rowett Institute stock cube used by Sengupta \& Howie (1948-9). In the present experiments the cube alone was used for diet 1 without the supplements of whole milk and green food to the mated does, which is required for its proper use as a stock-breeding diet (Thomson, 1936). Thus diet I of this paper differed from the diet $\mathrm{I}$ of Sengupta \& Howie (1948-9) who gave a daily supplement to breeding and lactating female mice of $5 \mathrm{ml}$. fresh liquid whole milk. The cube contained: wheat offal (bran) $17 \cdot 7$, wheat, whole ground $17 \cdot 7$, oats, Sussex-ground $17 \cdot 7$, maize, ground $8 \cdot 8$, 
barley, ground 8.8 , white-fish meal 4.5 , meat-and-bone meal 8.8 , dried skim milk 14 , dried yeast $\mathrm{I} \cdot 2$, sodium chloride 0.4 and cod-liver oil $0.4 \%$. Its chemical composition is given with that of the other diets in Table $\mathbf{I}$.

\section{Table I. Percentage composition of experimental diets}

\begin{tabular}{|c|c|c|c|c|c|c|c|c|c|}
\hline $\begin{array}{l}\text { Diet } \\
\text { no. }\end{array}$ & $\begin{array}{c}\text { Dry } \\
\text { matter }\end{array}$ & Protein & Fat & Fibre & $\begin{array}{l}\text { Carbo- } \\
\text { hydrate }\end{array}$ & Ash & Calcium & Phosphorus & $\begin{array}{l}\mathrm{Ca}: \mathrm{P} \\
\text { ratio }\end{array}$ \\
\hline I & $87 \cdot 6$ & 19.2 & 4.9 & $4 \cdot 8$ & $52 \cdot 7$ & 6.0 & $I \cdot 28$ & 0.99 & $1 \cdot 3$ \\
\hline 2 & $88 \cdot 3$ & 14.7 & 9.5 & $1 \cdot 3$ & $59 \cdot 9$ & $2 \cdot 9$ & 0.35 & 0.51 & 0.69 \\
\hline $3 \dagger$ & 44.0 & 9.9 & 4.0 & $2 \cdot 2$ & 25.0 & $2 \cdot 9$ & 0.6 & 0.47 & $1 \cdot 3$ \\
\hline 4 & $85 \cdot 3$ & 16.9 & $5^{\circ}$ & 5.9 & $5 I \cdot 9$ & $5 \cdot 6$ & 0.92 & 0.72 & $1 \cdot 3$ \\
\hline 5 & $89 \cdot 2$ & $19 \cdot 2$ & $9 \cdot I$ & $I \cdot I$ & $55 \cdot 6$ & $4 \cdot 2$ & 0.74 & 0.48 & $1 \cdot 5$ \\
\hline 24 & $84 \cdot 8$ & $12 \cdot 3$ & $5 \cdot 5$ & $1 \cdot 7$ & $63 \cdot 2$ & $2 \cdot 1$ & 0.19 & 0.42 & 0.45 \\
\hline
\end{tabular}

- See Table 2 for approximate amounts of dry matter and protein consumed by mated pairs on the roth day after birth of a litter.

$\uparrow$ Calculated for the proportions of cube, milk and cabbage eaten by mated pairs on the Ioth day after birth of a litter (see Table 2).

Diet 2 was the slightly modified diet B of Sherman (Sherman \& Campbell, 1924) and was the same as the diet 2 of Sengupta $\&$ Howie (I948-9). It consisted of whole ground wheat 66 , whole dried milk 33 and sodium chloride I \%.

Diet 3 was diet $x$ plus a daily supplement to each mated pair of up to $40 \mathrm{ml}$. fresh liquid whole milk and fresh cabbage ad lib. After being weaned at 21 days of age the young received only diet I, but the parent male and female received the supplement of milk and cabbage throughout the continuous-breeding period. During the infection test they received diet I without supplements.

Diet 4 was a commercially prepared cube of 'National Pig Food no. I for sows and weaners'. Its composition was: ground barley 28 , fine bran 14 , manioc meal $5^{\circ}$, extracted palm meal $8 \cdot 3$, palm-cake meal $5 \cdot 8$, white-fish meal $5 \cdot 8$, meat-and-bone meal $3 \cdot 0$, ground maize 16.5 , flaked maize 3.0 , maize-gluten meal $8 \cdot 3$, cod-liver oil 0.6 , ground limestone 0.5 and salt $0.4 \%$. This cube was given without supplements.

Diet 5 was a modification of diet 2, designed to increase the protein and calcium. It consisted of whole ground wheat 60 , casein (lactic, unextracted, Glaxo Laboratories Ltd.) 5 , whole dried milk 33 , sodium chloride I and calcium carbonate I $\%$.

Diet 24 was slightly modified from the diet A of Sherman (Sherman \& Campbell, 1924). It consisted of whole ground wheat 83 , whole dried milk 16 and sodium chloride $1 \%$. Sherman's original diets $A$ and $B$, of which our diets 24 and 2 respectively are slight modifications, were as follows: $\operatorname{diet} \mathrm{A}-$ dried whole milk I part, ground whole wheat 5 parts, sodium chloride equal to $2 \%$ of the weight of the wheat; diet B-dried whole milk I part, ground whole wheat 2 parts, sodium chloride equal to $2 \%$ of the weight of the wheat.

Diets I and 4 were given as cubes without supplements; diet 3 was given as a cube with supplements of up to $40 \mathrm{ml}$. fresh whole milk daily per mated pair and fresh cabbage ad lib.; diets 2, 5 and 24 were fed as a moist dough prepared by addition of $30 \mathrm{ml}$. water to $100 \mathrm{~g}$. diet. With all diets tap water was given ad lib. from drinking bottles. The diets also were given ad lib. except that for diet 3 the allowance of fresh whole milk per mated pair was restricted to $40 \mathrm{ml}$. daily. Food consumption, which 
was extremely variable, increased markedly during lactation even before the young themselves began to eat solid food, as they did about $15^{-1} 7$ days of age. For comparison between diets, approximate round figures for food consumed by mated pairs Io days after the birth of litters are given in Table 2 . The figures are based on observations made during this and other experiments.

Table 2. Food consumption on experimental diets expressed as approximate round figures based on observations during this and other similar experiments

\begin{tabular}{|c|c|c|c|c|c|c|c|c|}
\hline \multirow[b]{2}{*}{$\begin{array}{l}\text { Diet } \\
\text { no. }\end{array}$} & \multirow[b]{2}{*}{ Type of food } & \multicolumn{5}{|c|}{$\begin{array}{c}\text { Food consumed per mated pair (and } \\
\text { young*) on different days after birth } \\
\text { of a litter }(\mathrm{g} .) \\
\text { Day }\end{array}$} & \multicolumn{2}{|c|}{$\begin{array}{l}\text { Amount consumed } \\
\text { per mated pair on } \\
\text { the I oth day after } \\
\text { birth of a litter }\end{array}$} \\
\hline & & $\mathbf{I}$ & 5 & 10 & 15 & $\begin{array}{l}2 \mathrm{I} \\
\begin{array}{c}\text { (weaning } \\
\text { date) }\end{array}\end{array}$ & $\begin{array}{l}\text { Dry } \\
\text { matter } \\
\text { (g.) }\end{array}$ & $\begin{array}{c}\text { Protein } \\
\text { (g.) }\end{array}$ \\
\hline $\mathbf{1}$ & Cube & 18 & 20 & 22 & 28 & 34 & $19 \cdot 3$ & $4 \cdot 2$ \\
\hline 2 & Moist dough $\dagger$ & Io & 20 & 35 & 40 & 40 & $23 \cdot 7$ & $3 \cdot 9$ \\
\hline 3 & $\begin{array}{l}\text { Cube } \\
\text { Cabbage } \\
\text { Fresh liquid whole milk } \\
\text { (ml.) }\end{array}$ & $\begin{array}{r}5 \\
4 \\
15\end{array}$ & $\begin{array}{r}7 \\
5 \\
25\end{array}$ & $\begin{array}{r}25 \\
5 \\
30\end{array}$ & $\begin{array}{r}30 \\
5 \\
30\end{array}$ & $\left.\begin{array}{r}25 \\
5 \\
40\end{array}\right\}$ & $26 \cdot 3$ & $5 \cdot 9$ \\
\hline 4 & Cube & 18 & 20 & 22 & 28 & 34 & I $8 \cdot 8$ & 3.7 \\
\hline 5 & Moist dough $\dagger$ & 10 & I5 & 25 & 35 & 40 & $17 \cdot 1$ & $3 \cdot 7$ \\
\hline 24 & Moist dought & 10 & 20 & 35 & 40 & 40 & $22 \cdot 8$ & $3 \cdot 3$ \\
\hline
\end{tabular}

Records available. At the beginning of the experiment there were 156 mated pairs, twenty-six on each of the six diets. At the end of the experiment completed records were available for 134 of the pairs, twenty-two on diets $1,2,4$ and 5 , and twenty-three on diets 3 and 24. Of the twenty-two pairs whose records were not analysed, one was rejected because no young were born to the pair, sixteen because the female died before the experiment ended*, two because the female was killed because of vaginal prolapse, and three because the female was accidentally killed by the fall of a cage lid.

Statistical treatment of data. 'The records of the $\mathrm{I} 34$ pairs that completed the experiment were analysed by Mr M. H. Quenouille, Lecturer in Statistics at Aberdeen University. The full records are too extensive for publication but the summarized data presented here give an adequate account of the influence of the six diets on breeding performance of the pairs, growth of the young mice to maturity and resistance to infection both of the young and of the adults after the end of the breeding test.

\section{RESLLTS}

\section{Breeding performance}

To assess the relative efficiency of the diets under prolongation of the stress of continuous gestation and lactation, three periods of time were recognized: period $\mathrm{I}$, from first mating on 4 October 1948 to 12 December 1948; period 2, from I 2 December 1948

- Seven of the sixteen deaths followed blowing of a fuse in the heating circuit and a sharp fall of temperature from 68 to $42^{\circ} \mathrm{F}$. and nine were from causes not disclosed by post-mortem examination and culture for specific intestinal pathogenic bacteria. 
to I2 February 1949 and period 3, from I2 February I 949 to 24 May 1949, when the last litter was weaned. A full time-table of the main events of the breeding experiment is given in Table 3. Figures were available for the weights of mice weaned and for the numbers of mice born and weaned, the difference between the last two being the number that died before weaning. In the analysis of the numbers born, weaned and dead a square-root transformation was used to make the variances homogeneous and the

Table 3. Time-table of the main events in the breeding tests

\begin{tabular}{|c|c|c|}
\hline Date & Event & Notes \\
\hline \multirow[t]{2}{*}{$4 \cdot x \cdot 48$} & Experimental diets began & - \\
\hline & Mating began & $\begin{array}{l}\text { Males allowed to remain continuously in same } \\
\text { cages as females and young }\end{array}$ \\
\hline $23 \cdot x \cdot 4^{8}$ & Earliest first litters born & - \\
\hline $\begin{array}{l}\text { 4. x. } 48-\text { I2. xii. } 48 \\
\text { 12. xii. } 4^{8-12 . \text { ii. } 49} \\
\text { 12. ii. } 49-24 . \text { v. } 49\end{array}$ & $\left.\begin{array}{l}\text { Period } 1 \\
\text { Period } 2 \\
\text { Period } 3\end{array}\right\}$ & $\begin{array}{l}\text { Three unequal periods of time were recognized in } \\
\text { analysing the data. Period } 1 \text { included most first } \\
\text { and second litters, period } 2 \text { most third and fourth } \\
\text { litters and period } 3 \text { the subsequent litters }\end{array}$ \\
\hline 4. iv. 49 & Mating ended & $\begin{array}{l}\text { Males removed from breeding cages. Females left } \\
\text { to rear all litters already conceived }\end{array}$ \\
\hline 8-9. iv. 49 & $\begin{array}{l}\text { Fuse blown in animal } \\
\text { house; temperature fell } \\
\text { overnight from } 68 \text { to } \\
42^{\circ} \mathrm{F} \text {. }\end{array}$ & $\begin{array}{l}\text { Seven parent females died within the next } 4 \text { days, } \\
\text { their records were excluded from the analysis }\end{array}$ \\
\hline 24. $v$ & Last litter weaned & $一$ \\
\hline
\end{tabular}

means given are the squares of the mean square roots. In analysing the numbers born it was found that the few mice bearing no litter during any one period had an undue influence. After investigation, these zeros were changed to 6 for the purpose of the analysis. This had the effect of retaining a normal frequency distribution of the numbers born. If this change had not been made the frequency distribution would have been abnormal and the results would have been largely determined by the few failures to bear a litter. Thus it was better to change zero to 6 , a figure just below the lowest for mothers which bore any young. Since the numbers on the different diets were not the same the standard errors given are only approximate, but all statements about significance of differences are based on exact analyses.

Weight of young weaned. The weight of young weaned (Table 4) showed that diet 5 was consistently poor. In period 3 , diet 3 showed itself significantly better than diets 2 , 5 and 24. Diets $I$ and 4 were intermediate but the differences between these and the other diets were not significant.

Number of young weaned. The number of young weaned (Table 5) also showed the failure of diet 5 in comparison with diets 3 and 4 in all periods. In period 2, diet 1 was inferior to diet 3 .

Number of young born. For livestock production, the weight and number of young weaned are probably the best criteria for the efficiency of a diet, but it was also important to know if the diets influenced the numbers born. Analysis of the results ('Table 6) showed that in this respect also diet 5 was poor. Diets 3 and 4 were good in all periods and diet 4 was not significantly better than diet 3 in period 3 . The high number of young born on diet 4 has been noted in other unpublished experiments at this Institute. 
Table 4. Weight of young weaned on six different diets by female mice continuously mated for 6 months

\begin{tabular}{|c|c|c|c|c|c|}
\hline \multirow[b]{2}{*}{$\begin{array}{l}\text { Diet } \\
\text { no. }\end{array}$} & \multicolumn{4}{|c|}{ Mean weight of young weaned per femal } & \multirow[b]{2}{*}{ Statistically significant differences } \\
\hline & $\begin{array}{l}\text { mated } \\
\text { females }\end{array}$ & $\begin{array}{l}\text { Period I } \\
\text { (g.) }\end{array}$ & $\begin{array}{l}\text { Period 2* } \\
\text { (g.) }\end{array}$ & $\begin{array}{l}\text { Period } 3^{\circ} \\
\text { (g.) }\end{array}$ & \\
\hline $\begin{array}{l}1 \\
2\end{array}$ & $\begin{array}{l}22 \\
22\end{array}$ & $\begin{array}{l}77 \cdot 0 \\
87 \cdot 2\end{array}$ & $\begin{array}{l}71 \cdot 1 \\
90 \cdot 5\end{array}$ & $\left.\begin{array}{r}103 \cdot 5 \\
81 \cdot 3\end{array}\right)$ & $\begin{array}{l}\text { Period } \mathrm{I} \text {. Diet } 5 \text { less than all others } \\
\text { except diet } x\end{array}$ \\
\hline 3 & 23 & $98 \cdot 3$ & 117.5 & $130 \cdot 9$ & \\
\hline 4 & 22 & 85.7 & 103.8 & 110.4 & Period 2. Diet 5 less than diets 3 and 4 . \\
\hline 5 & 22 & $47 \cdot 9$ & $55^{\circ} \cdot 6$ & 73.3 & \\
\hline 24 & 23 & $89 \cdot 9$ & $86 \cdot 9$ & $88 \cdot 1$ & $\begin{array}{l}\text { Period } 3 \text {. Diet } 3 \text { greater than diets } 2 \text {, } \\
5 \text { and } 24\end{array}$ \\
\hline inda & & $\pm 15 \cdot 4$ & $\pm 17 \cdot 6$ & $\pm 20 \cdot 1^{\prime}$ & \\
\hline
\end{tabular}

- See note in Table 3 for explanation of periods $1-3$.

Table 5. Number of young weaned on six different diets by female mice continuously mated for 6 months

\begin{tabular}{|c|c|c|c|c|c|}
\hline \multirow{2}{*}{$\begin{array}{l}\text { Diet } \\
\text { no. }\end{array}$} & \multirow{2}{*}{$\begin{array}{l}\text { No. of } \\
\text { mated } \\
\text { females }\end{array}$} & \multicolumn{3}{|c|}{ Mean no. of young weaned per female } & \multirow[b]{2}{*}{ Statistically significant differences } \\
\hline & & Period I* & Period 2* & Period $3 *$ & \\
\hline 1 & 22 & $8 \cdot 9$ & $7 \cdot 5$ & 10.0) & Period $x$. Diet 5 less than diets 3 and 4 \\
\hline 2 & 22 & 10.4 & $10 \cdot 6$ & $9 \cdot 5$ & \\
\hline 3 & 23 & $\mathbf{I} 1 \cdot 2$ & $14 \cdot 1$ & $13 \cdot 7$ & Period 2. Diet 5 less than diets 3 and 4 . \\
\hline 4 & 22 & $11 \cdot 7$ & II $\cdot 8$ & $\mathrm{II} \cdot 8$ & Diet I less than diet 3 \\
\hline 5 & 22 & $6 \cdot 2$ & $5 \cdot 7$ & $6 \cdot 7$ & \\
\hline 24 & 23 & $9 \cdot 6$ & $9 \cdot 9$ & $9 \cdot 8$ & Period 3 . Diet 5 less than diets 3 and 4 \\
\hline $\begin{array}{l}\text { Standa } \\
\text { differe }\end{array}$ & ror of & $\pm 2 \cdot 5$ & $\pm 2 \cdot 9$ & $\pm 3 \cdot 1$ & \\
\hline
\end{tabular}

- See note in Table 3 for explanation of periods $I-3$.

Table 6. Number of young born on six different diets to female mice continuously mated for 6 months

\begin{tabular}{|c|c|c|c|c|c|}
\hline \multirow{2}{*}{$\begin{array}{l}\text { Diet } \\
\text { no. }\end{array}$} & \multirow{2}{*}{$\begin{array}{l}\text { No. of } \\
\text { mated } \\
\text { females }\end{array}$} & \multicolumn{3}{|c|}{ Mean no. of young born per female } & \multirow[b]{2}{*}{ Statistically significant differences } \\
\hline & & Period $1 *$ & Period 2* & Period $3 *$ & \\
\hline$I$ & 22 & $13 \cdot 7$ & $I x \cdot 8$ & $15 \cdot 5)$ & Period I. Diet 5 less than diets 3 and 24 \\
\hline 2 & 22 & 13.8 & 14.7 & 14.8 & \\
\hline 3 & 23 & $\begin{array}{r}14.4 \\
13.5\end{array}$ & $\begin{array}{l}17.4 \\
16.6\end{array}$ & $\begin{array}{r}17 \cdot 8 \\
27.6\end{array}$ & Period 2. Diets 3 and 4 greater than \\
\hline $\begin{array}{l}4 \\
5\end{array}$ & $\begin{array}{l}22 \\
22\end{array}$ & $\begin{array}{l}13.5 \\
11.5\end{array}$ & $\begin{array}{l}16 \cdot 6 \\
12 \cdot 0\end{array}$ & $\left.\begin{array}{l}21 \cdot 6 \\
15 \cdot 3\end{array}\right\}$ & diets $I$ and 5 \\
\hline 24 & 23 & 14.5 & 14.4 & 17.0 & $\begin{array}{l}\text { Period 3. Diet } 4 \text { greater than diets I, } \\
2 \text { and } 5\end{array}$ \\
\hline and & ror of & $\pm 1 \cdot 5$ & $\pm 2 \cdot 2$ & $\pm 2.7)$ & \\
\hline
\end{tabular}

- See note in Table 3 for explanation of periods $1-3$. 
Number of deaths before weaning. The viability of the young is also a matter of importance in judging the efficiency of a diet for reproduction. The figures (Table 7) showed only that the greater number of young born on diet 4 was offset in period 3 by a high number of deaths before weaning. Otherwise the diets did not differ in the numbers of young dying between birth and weaning.

Table 7. Number of young dying before weaning at 21 days. The young were born to, and reared by, female mice on six different diets, mated continuously for 6 months

\begin{tabular}{|c|c|c|c|c|c|}
\hline \multirow{2}{*}{$\begin{array}{c}\text { Diet } \\
\text { no. }\end{array}$} & \multirow{2}{*}{$\begin{array}{l}\text { No. of } \\
\text { mated } \\
\text { females }\end{array}$} & \multicolumn{3}{|c|}{ Mean no. of young dying per female } & \multirow[b]{2}{*}{ Statistically significant differences } \\
\hline & & Period I* & Period $2 *$ & Period $3 *$ & \\
\hline I & 22 & 2.4 & I.7 & $2 \cdot 4$ & \\
\hline 2 & 22 & $1 \cdot 7$ & 3.4 & 3.6 & \\
\hline 3 & 23 & $1 \cdot 7$ & $\mathbf{r} \cdot 7$ & 3.5 & Period 2$\}$ No differences between diets \\
\hline 4 & 22 & $1 \cdot 8$ & 3.4 & $7 \cdot 6$ & \\
\hline 5 & 22 & $3 \cdot 6$ & $3 \cdot 2$ & $6 \cdot 2$ & Period 3. Diet 4 greater than diets 1 and 3 \\
\hline $\begin{array}{l}24 \\
\operatorname{tandar}\end{array}$ & $\begin{array}{c}23 \\
\text { rror of }\end{array}$ & $\begin{array}{r}2 \cdot 1 \\
\pm 1 \cdot 2\end{array}$ & $\begin{array}{r}2 \cdot 1 \\
\pm I \cdot 5\end{array}$ & $\begin{array}{r}4.1 \\
\pm 2.0\end{array}$ & \\
\hline
\end{tabular}
differences

- See note in Table 3 for explanation of periods $1-3$. Since the values are squared mean square roots the means in this table do not correspond to the difference between the means of Tables 5 and 6 .

Summary of reproduction tests. Apparently the diets differed chiefly in the weight of young weaned. Over the whole period of the test the most clearly established and consistent points are the superiority of diet 3 and the failure of diet 5 (Table 8).

Table 8. Summary of reproduction tests

(Results in Tables $4 \rightarrow 7$ combined for periods $\mathrm{x}-3$ )

\begin{tabular}{|c|c|c|c|c|c|}
\hline $\begin{array}{l}\text { Diet } \\
\text { no. }\end{array}$ & $\begin{array}{l}\text { No. of } \\
\text { mated } \\
\text { females }\end{array}$ & $\begin{array}{l}\text { Mean weight of } \\
\text { young weaned } \\
\text { per female } \\
\text { (g.) }\end{array}$ & $\begin{array}{l}\text { Mean no. } \\
\text { of young } \\
\text { weaned per } \\
\text { female }\end{array}$ & $\begin{array}{l}\text { Mean no. } \\
\text { of young } \\
\text { born per } \\
\text { female }\end{array}$ & $\begin{array}{l}\text { Mean no. } \\
\text { of young } \\
\text { dying per } \\
\text { female }\end{array}$ \\
\hline $\mathbf{I}$ & 22 & $25 I \cdot 6$ & $26 \cdot 4$ & $4 I \cdot 0$ & $6 \cdot 5$ \\
\hline 2 & 22 & $259^{\circ} 0$ & 30.5 & $43 \cdot 3$ & $8 \cdot 7$ \\
\hline 3 & 23 & $346 \cdot 7$ & $39 \cdot 0$ & $49 \cdot 6$ & $6 \cdot 9$ \\
\hline 4 & 22 & $299^{\circ} 9$ & $35 \cdot 3$ & $5 I \cdot 7$ & $12 \cdot 8$ \\
\hline 5 & 22 & $176 \cdot 8$ & $18 \cdot 6$ & $38 \cdot 8$ & I $3 \cdot 0$ \\
\hline 24 & 23 & $264 \cdot 9$ & $29 \cdot 3$ & $45 \cdot 9$ & $8 \cdot 3$ \\
\hline \multicolumn{2}{|c|}{ Standard error of differences } & $\pm 30 \cdot 84$ & $\pm 4^{\circ} 93$ & \pm 3.79 & $\pm 2 \cdot 77$ \\
\hline \multicolumn{2}{|c|}{$\begin{array}{l}\text { Statistically significant } \\
\text { differences }\end{array}$} & $\begin{array}{l}\text { Diet } 3 \text { greater. } \\
\text { than diets } 1,2 \text {, } \\
5 \text { and } 24, \text { and } \\
\text { diet } 5 \text { less than } \\
\text { the rest }\end{array}$ & $\begin{array}{l}\text { Diet } 3 \text { greater } \\
\text { than diets I, } 2 \text {, } \\
5 \text { and } 24 \text {, and } \\
\text { diet } 5 \text { less than } \\
\text { the rest except } \\
\text { diet I }\end{array}$ & $\begin{array}{l}\text { Diet } 3 \text { greater } \\
\text { than diets I and } \\
5 \text {; diet } 5 \text { less } \\
\text { than diets } 3 \\
\text { and } 4 ; \text { diet } 4 \\
\text { greater than } \\
\text { diets } 1 \text { and } 5\end{array}$ & $\begin{array}{l}\text { Diets } 1,3 \text { and } \\
24 \text { less than } \\
\text { diets } 4 \text { and } 5\end{array}$ \\
\hline
\end{tabular}

- Since the values are squared mean square roots the figures in this column do not correspond to the differences between those of the two preceding columns.

\section{Growth test}

As already described, the diets were tested for their capacity to support growth from weaning at 3 weeks to maturity at II weeks of age. In analysing the data the mean weight at I I weeks of age was adjusted for the weaning weight since, for this observation 
it was desired to take account only of diet effects after weaning. 'This was done by using an analysis of covariance to eliminate the effect of differences in weaning weight.

At this stage diet 3 was in effect the same as diet $x$, since the supplements of milk and cabbage were withdrawn at weaning. The results (Table 9) show that the highest weaning weights were those for diets 3 and 24 and that the lowest gains between 3 and I I weeks of age were made by mice fed on diets I and 4 .

Table 9. Growth of mice between 3 and I I weeks of age. The mice, from first litters, were born, suckled, and reared on the experimental diets

(Weights at II weeks adjusted for weaning weights (see p. 18I))

\begin{tabular}{|c|c|c|c|c|c|c|c|c|c|}
\hline & & Males & & & Females & & & xes comb & ined \\
\hline & & Mear & wt. at & & Mean & wt. at & & Mean & wt. at \\
\hline $\begin{array}{l}\text { Diet } \\
\text { no. }\end{array}$ & $\begin{array}{c}\text { No. of } \\
\text { mice }\end{array}$ & $\begin{array}{l}3 \text { weeks } \\
\text { (g.) }\end{array}$ & $\begin{array}{c}\text { I I weeks } \\
\text { (adjusted) } \\
\text { (g.) }\end{array}$ & $\begin{array}{l}\text { No. of } \\
\text { mice }\end{array}$ & $\begin{array}{l}3 \text { weeks } \\
\text { (g.) }\end{array}$ & $\begin{array}{c}\text { I I weeks } \\
\text { (adjusted) } \\
\text { (g.) }\end{array}$ & $\begin{array}{c}\text { No. of } \\
\text { mice }\end{array}$ & $\begin{array}{l}3 \text { weeks } \\
\text { (g.) }\end{array}$ & $\begin{array}{c}\text { I I weeks } \\
\text { (adjusted) } \\
\text { (g.) }\end{array}$ \\
\hline I & II & $7 \cdot 2$ & $23 \cdot 0$ & 14 & $7 \cdot 4$ & $20 \cdot 2$ & 25 & $7 \cdot 3$ & $21 \cdot 6$ \\
\hline 2 & 18 & $8 \cdot 0$ & $26 \cdot 3$ & 18 & $7 \cdot 6$ & $22 \cdot 3$ & 36 & $7 \cdot 8$ & $24 \cdot 3$ \\
\hline $3^{*}$ & 20 & $8 \cdot 8$ & 24.8 & 17 & $8 \cdot 8$ & $21 \cdot 9$ & 37 & $8 \cdot 8$ & 23.4 \\
\hline 4 & I 4 & $7 \cdot 9$ & 24.0 & 17 & $7 \cdot 6$ & $19 \cdot 6$ & $3^{I}$ & $7 \cdot 8$ & $21 \cdot 8$ \\
\hline 5 & 9 & $7 \cdot 3$ & 24.4 & I 3 & $7 \cdot 3$ & $21 \cdot 5$ & 22 & $7 \cdot 3$ & 23.0 \\
\hline 24 & II & $8 \cdot 8$ & $26 \cdot 4$ & 10 & $8 \cdot 3$ & $2 I \cdot I$ & 21 & $8 \cdot 6$ & $23 \cdot 7$ \\
\hline $\begin{array}{r}\text { Standar } \\
\text { differe }\end{array}$ & $\begin{array}{l}\text { rror of } \\
s\end{array}$ & \pm 0.5 & $\pm I \cdot 0$ & - & \pm 0.5 & $\pm 1 \cdot 0$ & - & \pm 0.4 & \pm 0.7 \\
\hline $\begin{array}{l}\text { Regress } \\
\text { weanir }\end{array}$ & $\begin{array}{l}\text { on } \\
\text { eight }\end{array}$ & $b=0.93 \pm$ & 20 & & $=0.50 \pm 0$ & 19 & & - & \\
\hline
\end{tabular}

Statistically significant differences

Males. Weaning weights greater for diets 3 and 24 than for diets 1 and 5. Adjusted 11 -week weights greater for diets 2 and 24 than for diets 1 and 4.

Females. Weaning weights greater for diet 3 than for diets I, 2, 4 and 5. Adjusted II-week weights greater for diets 2,3 and 5 than for diet 4; greater also for diet 2 than for diet 1 .

Sexes combined. Weaning weights greater for diets 3 and 24 than for all other diets. Adjusted I I-week weights less for diets $I$ and 4 than for all other diets.

- The supplements of milk and cabbage were withdrawn at weaning and from then onwards mice received only diet-I cube.

\section{Infection tests}

Five infection tests were carried out, three on offspring of the mated pairs and one each on the parent males and parent females. The results (Tables Io and II) show that diet had some influence on survival rate after infection. Since the survival rates of animals on the different diets appeared to be fairly consistent in the different tests, an analysis of variance was carried out on the survival rates transformed to make the variance homogeneous. This showed that, over all the five tests, differences in survival due to diet just failed to be significant at the $5 \%$ level.

\section{DISCUSSION}

These results must be considered against a background of the confused state of our present knowledge about diet and resistance to infection. One negative conclusion may be safely drawn: because a diet is better than another for reproduction and growth it 
Table 10. Summary of survival rates in infection tests with mice fed on six experimental diets

\begin{tabular}{|c|c|c|c|c|c|c|c|c|c|c|}
\hline \multirow{2}{*}{$\begin{array}{l}\text { Test } \\
\text { no. }\end{array}$} & \multirow[b]{2}{*}{ Infection } & \multirow[b]{2}{*}{ Animals } & \multirow{2}{*}{$\begin{array}{c}\text { Age at } \\
\text { infection } \\
\text { (weeks) }\end{array}$} & \multirow{2}{*}{$\begin{array}{l}\text { Diet } \\
\text { no. }\end{array}$} & \multicolumn{2}{|c|}{ No. infected } & \multicolumn{2}{|c|}{$\begin{array}{l}\text { No. alive } 28 \\
\text { days after } \\
\text { infection }\end{array}$} & \multicolumn{2}{|c|}{$\begin{array}{l}\text { Survival } \\
\text { rate }(\%)\end{array}$} \\
\hline & & & & & Males & Females & Males & Females & Males & Females \\
\hline \multirow[t]{5}{*}{ I } & Tubercle & First litters & $6 \cdot 5-7.5$ & $\begin{array}{l}\mathbf{I} \\
\mathbf{2}\end{array}$ & $\begin{array}{l}14 \\
21\end{array}$ & $\begin{array}{l}\text { I4 } \\
\text { 2I }\end{array}$ & $\begin{array}{l}\text { II } \\
\text { I } 8\end{array}$ & $\begin{array}{l}\text { II } \\
\text { I5 }\end{array}$ & $\begin{array}{l}79 \\
86\end{array}$ & $\begin{array}{l}79 \\
71\end{array}$ \\
\hline & & & & 3 & 22 & 23 & 9 & 9 & 41 & 39 \\
\hline & & & & 4 & 18 & 20 & ro & 6 & 56 & 30 \\
\hline & & & & 5 & 13 & 14 & 8 & 7 & 62 & 50 \\
\hline & & & & 24 & 13 & II & 5 & 8 & 38 & 73 \\
\hline \multirow[t]{6}{*}{2} & Salmonella & Third litters & $7 \cdot 3-9.0$ & I & 12 & 13 & II & 9 & 92 & 69 \\
\hline & & & & 2 & 20 & 33 & 18 & 25 & 90 & 76 \\
\hline & & & & 3 & 46 & 29 & $3 \mathrm{r}$ & I 5 & 67 & 52 \\
\hline & & & & 4 & 20 & 7 & 17 & 7 & 85 & 100 \\
\hline & & & & 5 & 16 & 17 & I3 & II & 81 & 65 \\
\hline & & & & 24 & 26 & 21 & 22 & 13 & 85 & 62 \\
\hline \multirow[t]{6}{*}{3} & Tubercle & First litters & $14.0-15.0$ & $\mathbf{I}$ & 6 & 11 & 5 & 8 & 83 & 73 \\
\hline & & & & 2 & 17 & 18 & 15 & 12 & 88 & 67 \\
\hline & & & & 3 & 18 & 15 & 12 & 11 & 67 & 73 \\
\hline & & & & 4 & 14 & 16 & 14 & 12 & 100 & 75 \\
\hline & & & & 5 & 7 & II & 7 & 6 & 100 & 55 \\
\hline & & & & 24 & 9 & 7 & 9 & 5 & $1 \infty$ & 71 \\
\hline \multirow[t]{6}{*}{4} & Salmonella & Parent males & $36 \cdot 0-37 \cdot 0$ & $\mathbf{I}$ & 26 & - & 17 & - & 65 & - \\
\hline & (On experiment & tal diets for & & 2 & 26 & - & 15 & - & 58 & - \\
\hline & 26 weeks) & & & 3 & 26 & - & 21 & - & 81 & - \\
\hline & & & & 4 & 26 & - & 21 & - & $8 I$ & - \\
\hline & & & & 5 & 26 & - & 15 & - & $5^{8}$ & - \\
\hline & & & & 24 & 26 & - & 16 & - & 62 & - \\
\hline \multirow[t]{6}{*}{5} & Salmonella & Parent females & $44 \cdot 0-45 \cdot 0$ & $\mathbf{I}$ & - & $23^{*}$ & - & 17 & - & 74 \\
\hline & (On experimen & tal diets for & & 2 & - & 22 & - & 15 & - & 68 \\
\hline & 34 weeks. Inf & ection I week & & 3 & - & 23 & - & II & - & 48 \\
\hline & after last youn & gg weaned) & & 4 & - & 22 & - & 18 & - & 82 \\
\hline & & & & 5 & - & 22 & - & 8 & - & 36 \\
\hline & & & & 24 & - & 23 & - & I4 & - & $6 \mathrm{I}$ \\
\hline
\end{tabular}

- Includes one mouse which bore no young. She died 14 days after infection.

does not follow that it will confer superior resistance to infection. The reverse, indeed, has already been established for certain infections caused by viruses (see, for example, references quoted by Howie (1948-9, p. 336)) and some infections caused by anaerobic bacteria, e.g. infectious enterotoxaemia of sheep caused by Clostridium welchii type $\mathrm{D}$ (Bacillus ovitoxicus) (Bennetts, 1932) and black-quarter of sheep caused by Clostridium chauvoei (Minett, 1948). In the present work salmonella and tubercle were used as test infections. Both infections are caused by aerobic bacteria and both have been frequently used by earlier workers in this field. In the three infection tests where dietary effects were significant it will be seen that mice on diet 3 had low survival rates (see tests $\mathrm{X}, 2$ and 5 in Tables Io and II). In the reproduction tests, on the other hand, diet 3 appeared better than any of the others and it was also a good diet for growth (Tables 4-9). Diet 5 was consistently poor for reproduction, but the survival rates after infection were not so low with diet 5 as with diet 3 , except in one of the three tests (test no. 5) where a significant dietary effect was observed. 
Table I I. Statistical analysis to test for presence or absence of a dietary influence on the results of infection tests

\begin{tabular}{|c|c|c|c|c|c|c|c|}
\hline \multirow[b]{3}{*}{$\begin{array}{l}\text { Test } \\
\text { no. }\end{array}$} & \multicolumn{7}{|c|}{ (See Table 10 for results) } \\
\hline & \multicolumn{3}{|c|}{$x_{(s)}^{2}$} & \multicolumn{3}{|c|}{$P$} & \multirow[b]{2}{*}{ Remarks } \\
\hline & Males & Females & $\begin{array}{c}\text { Sexes } \\
\text { combined }\end{array}$ & Males & Females & $\begin{array}{l}\text { Sexes } \\
\text { combined }\end{array}$ & \\
\hline $\mathbf{I}$ & $13 \cdot 85$ & $14 \cdot 31$ & $22 \cdot 17$ & $<0.02$ & $<0.02$ & $<0.001$ & $\begin{array}{l}\text { Significant dietary effect. Diets } \\
3 \text { and } 4 \text { showed much lower sur- } \\
\text { vival rates than the others }\end{array}$ \\
\hline 2 & $7 \cdot 52$ & $7 \cdot 92$ & $11 \cdot 22$ & $>0 \cdot x$ & $>0.1$ & $<0.05$ & $\begin{array}{l}\text { Dietary effect just significant for } \\
\text { sexes combined. Diet } 3 \text { had a much } \\
\text { lower survival rate than any other; } \\
\text { but diet } 4 \text { had the highest survival } \\
\text { rate }\end{array}$ \\
\hline 3 & $-\cdot$ & 一 & $3 \cdot 85$ & - & - & $>0.5$ & $\begin{array}{l}\text { Numbers too small for separate } \\
\text { testing of each sex. No significant } \\
\text { dietary effect for sexes combined }\end{array}$ \\
\hline 4 & $6 \cdot 90$ & - & - & $>0.2$ & - & - & No significant dietary effect \\
\hline 5 & - & 13.44 & - & - & $<0.02$ & - & $\begin{array}{l}\text { Significant dietary effect. Much } \\
\text { lower survival rates with diets } \\
3 \text { and } 5 \text { than with other diets }\end{array}$ \\
\hline $1-5 *$ & $\begin{array}{c}\text { Analy } \\
\text { forn }\end{array}$ & $\begin{array}{l}\text { sis of vari } \\
\text { hed to ma }\end{array}$ & $\begin{array}{l}\text { ance perfo } \\
\text { ke variabil }\end{array}$ & ned on & $\begin{array}{l}\text { rvival rat } \\
\text { able }\end{array}$ & 8 trans- & $\begin{array}{l}\text { Dietary effect just fails to reach } \\
\text { significance at the } 5 \% \text { level }\end{array}$ \\
\hline
\end{tabular}

- Combined results.

Having reached this point it is worth considering the next step. It is tempting to speculate about possible explanations for the dietary effects observed; in our opinion this is premature since they are neither great enough nor consistent enough. In this respect we remain where we were when these experiments were begun; but we are encouraged to continue our comparisons of good and poor natural diets. Although the differences observed between diets in the present experiments were neither of the magnitude hoped for nor in the expected direction, they none the less afford some encouragement for supposing that interesting phenomena may still await discovery. The use of infection as a stress for testing diets may well elicit information about nutrient values not disclosed by tests of reproduction and growth. If diet 3 is not a good source of some unknown substance, essential for resistance to infection, the very fact of its being a good diet for rapid growth before and after weaning may only serve to increase the need for whatever is lacking.

Moreover, our attempts to improve diet 2, the slightly modified diet B of Sherman, disclosed how easily this diet may be unbalanced-in our experiments by reduction of wheat combined with increases in casein and chalk. The comparative failure of reproduction with diet 5 is so clear-cut that it seems to deserve, and is receiving, separate investigation.

Our experiments confirm that there is something in the belief of a relation between nutrition and resistance to infection. The facts of the relationship remain confused, but so long as our efforts to disentangle them continue to produce new facts about nutrition, however unexpected and inexplicable these may be for the present, we think it worth presenting what we find and continuing the inquiry. 


\section{SUMMARY}

I. Six experimental diets of natural food were tested in mice for their capacity to support reproduction, growth, and resistance to infection.

2. There were clear-cut differences in the relative efficiency of the diets for reproduction and growth. Differences in the relative efficiency of the diets for resistance to infection with tubercle bacilli or salmonella organisms were less marked and consistent, and the best diet for reproduction (diet 3), which was also a good diet for growth, was the poorest for resistance to infection.

3. The dietary effects upon resistance to infection were quite clear in some tests but less marked in others. The relatively low order of the differences between diets and the inconsistency of the results between different tests renders it necessary to continue inquiry into the relations between diet and resistance to infection.

4. When $6 \%$ of the whole wheat in the B diet of Sherman was replaced by $5 \%$ casein and I \% calcium carbonate (diet 5), the capacity of the diet to support reproduction of mice was seriously impaired.

We are very grateful to Mr M. H. Quenouille for the statistical analyses.

\section{REFERENCES}

Bennetts, H. W. (1932). Bull. Coun. sci. industr. Res. Aust. no. 57.

Bruce, H. M. \& Emmens, C. W. (1948). F. Hyg., Camb., 46, 3 I5.

Clark, P. F., McClung, L. S., Pinkerton, H., Price, W. H., Schneider, H. A. \& Trager, W. (1949). Bact. Rev. 13, 99.

Howie, J. W. (1948-9). Brit. F. Nutrit. 2, 331.

Minett, F. C. (1948). F. comp. Path. 58, 245.

Schneider, H. A. (1946). Y. exp. Med. 84, 305.

Schneider, H. A. (1948). Ү. exp. Med. 87, 103.

Schneider, H. A. (1949). Trans. Amer. Ass. Cereal Chem. 7, 4.

Schneider, H. A., \& Webster, L. T. (1945). F. exp. Med. 8r, 359.

Sengupta, S. R. \& Howie, J. W. (1948-9). Brit. F. Nutrit. 2, 3 1 3.

Sherman, H. C. \& Campbell, H. L. (1924). F. biol. Chem. 60, 5.

Thomson, W. (1936). F. Hyg., Camb., 36, 24. 